\title{
Does blending canola meal with other protein sources improve production responses in lactating dairy cows? A multilevel mixed-effects meta-analysis
}

\author{
R. Martineau, ${ }^{1 *}$ D. R. Ouellet, ${ }^{2}$ and H. Lapierre ${ }^{2}$ \\ ${ }^{1}$ Département des Sciences Animales, Université Laval, Québec, QC, Canada, G1V 0A6 \\ ${ }^{2}$ Research and Development Centre, Agriculture and Agri-Food Canada, Sherbrooke, QC, Canada, J1M 0C8
}

\section{ABSTRACT}

The objective of this meta-analysis was to evaluate the effect of blending canola meal (CM) with other protein sources on production responses in lactating dairy cows. To evaluate this effect, a data set was assembled containing 22 studies reporting at least 3 isonitrogenous dietary treatments (total of 74 treatment means). Each study needed to report 1 diet with CM $<0.3 \mathrm{~kg} / \mathrm{d}, 1$ or more diets consisting of CM blended with another protein source, and 1 diet with $\mathrm{CM}$ as the main protein source in the protein supplement $(>85 \%)$. The crude protein $(\mathrm{CP})$ concentration of $\mathrm{CM}$ averaged $37.4 \pm 3.09 \%$ (dry matter basis), and the predictor of interest was the intake of $\mathrm{CP}$ from $\mathrm{CM}$, which averaged $0.46 \pm 0.413 \mathrm{~kg} / \mathrm{d}$ among studies. The maximal CP from CM ranged from 0.47 to $1.55 \mathrm{~kg} / \mathrm{d}$ among studies. The quadratic relationship between $\mathrm{CP}$ from $\mathrm{CM}$ and responses in milk true protein concentration was significant, the maximum response $(3.19 \%)$ being reached at $0.79 \mathrm{~kg}$ of $\mathrm{CP}$ from $\mathrm{CM}$; the quadratic relationships were not significant for the other dependent variables. Responses in dry matter intake; yields of milk, energycorrected milk, and milk true protein; and apparent $\mathrm{N}$ efficiency were related positively to $\mathrm{CP}$ from $\mathrm{CM}$ and negatively for responses in milk fat and milk urea $\mathrm{N}$ concentrations. Remembering that diets were isonitrogenous within studies, this indicates no nutritional benefit of blending CM with another protein source. Taken together, the results indicate that the whole-body $\mathrm{N}$ utilization efficiency by the dairy cow improved and that more dietary protein was used to synthesize milk protein when CM was used as the sole protein source in the protein supplement up to $1.55 \mathrm{~kg} / \mathrm{d}$.

Key words: canola meal, rapeseed, protein supplement, metafor, dairy cow

Received October 30, 2018.

Accepted January 31, 2019.

*Corresponding author: roger.martineau@canada.ca

\section{INTRODUCTION}

Traditionally, rapeseed coproducts were not regarded as suitable feedstuff for dairy cows because of high concentrations of glucosinolate, tannin, phytate, and other compounds that could negatively affect DMI and milk production (Abbadi and Leckband, 2011). It was not until the early 1970s that Canadian producers developed varieties of Brassica spp. with low concentrations of erucic acid $(<2 \%)$ in the oil and glucosinolates $(<30 \mu \mathrm{mol} / \mathrm{g})$ in the defatted meal. These varieties are named "canola" in North America and "zero-zero," "double-zero," or "double-low" rapeseed in Europe (Shahidi, 1990). In Finland, all rapeseed varieties had low glucosinolate levels after 1985; however, varieties with high glucosinolate levels were still used in some European countries in the 1990s because early doublezero varieties had lower yields and farmers were using their own seeds (Seppo Ahvenjärvi, MTT Agrifood Research, Jokioinen, Finland, personal communication; Katja Hämäläinen, Boreal Plant Breeding Ltd., Jokioinen, Finland, personal communication). In many feed databases, canola meal (CM) and double-zero rapeseed meal are considered the same ingredients (Sauvant et al., 2004); thus, they are referred to as CM in this paper.

Over the past 4 decades, a large amount of literature has been published on the use of CM solely or in comparison with other protein sources in lactating dairy cows. Hill (1991) reviewed 10 studies comparing production responses of cows supplemented with soybean meal (SBM) or CM (up to $4.1 \mathrm{~kg} / \mathrm{d}$ ) and concluded that CM could be fed as freely as SBM and that milk composition was equally satisfactory from either feed. However, recent meta-analyses have shown an increase in production responses with $\mathrm{CM}$ versus SBM. Huhtanen et al. (2011) reviewed 51 European studies and reported greater marginal milk protein yield (MPY) responses in CM versus SBM studies as dietary CP concentration increased. Martineau et al. (2013, 2014) reviewed 27 studies with isonitrogenous dietary treatments and reported that the complete substitution of a protein source by $\mathrm{CM}$ increased responses 
in MPY and plasma essential AA concentrations and decreased responses in BUN and MUN concentrations, indicating that dietary $\mathrm{CP}$ was used more efficiently in CM diets versus diets supplemented with other protein sources. Because of the specific objectives and selected meta-designs in these meta-analyses, the data set did not include studies in which CM was blended with another protein source (e.g., 0.5:0.5 for SBM and CM in the protein supplement, respectively). Therefore, the effect of blending CM with other protein sources was not evaluated in these meta-analyses.

It is often suggested that dairy farmers should use a blend of protein sources to warrant the best AA profile supply and avoid a limitation in some essential AA, particularly Lys and Met (Schingoethe, 1996). If that would apply to $\mathrm{CM}$, the marginal production response to increasing supply of $\mathrm{CM}$ in isonitrogenous diets would follow a curvilinear pattern, indicating that blending $\mathrm{CM}$ with other protein sources increases production responses, which plateau or even decrease at high CM intake (i.e., plateau- or bell-shaped pattern between production responses and CM intake). This question deserves further investigation because nutritionists have to make price-related and nutritionally sound decisions to justify the selection of protein sources in dairy rations. A bell-shaped pattern was present between responses in milk true protein yield (MTPY) and the dietary proportion of $\mathrm{CM}$ in the study of Mulrooney et al. (2009), but the quadratic relationship was not significant, likely due to a lack of statistical power. In contrast, a similar bell-shaped pattern was present in the studies of Swanepoel et al. (2014) and Robinson and Swanepoel (2018), and the quadratic relationship was highly significant because the statistical analysis was done using a very large sample size $(\mathrm{n} \geq 523)$, although dietary treatments were allocated on a pen basis (n $=4$ ). A meta-analysis is therefore needed to provide additional statistical power to determine whether such a quadratic relationship does exist between production responses and the graded inclusion of $\mathrm{CM}$ in the ration.

It is likely that CM does not need to be blended with other protein sources in dairy cow rations and that only linear relationships will be significant in the meta-regressions, in line with previous meta-analyses conducted by Huhtanen et al. (2011) and Martineau et al. (2013, 2014). Indeed, there are several nutritional benefits associated with feeding $\mathrm{CM}$ in dairy cow diets; CM (1) is an efficient RDP source, providing AA and peptides readily incorporated into microbial $\mathrm{CP}$ (MCP; Piepenbrink and Schingoethe, 1998; Bach et al., 2005), (2) has an excellent AA profile relative to the composition of other protein sources and milk protein (NRC, 2001), (3) improves the profile of Lys and Met in duodenal digesta (Robinson, 2010), and (4) increases plasma concentrations of essential AA (Martineau et al., 2014). The positive effect of $\mathrm{CM}$ on duodenal flows of Met and Lys is important because they are colimiting AA for milk protein synthesis on a wide variety of North American dairy cow diets: Met for SBM-supplemented diets (Illg et al., 1987) and Lys for corn-based diets (Schwab et al., 1992).

If relationships between production responses and $\mathrm{CM}$ inclusion in isonitrogenous diets are linear (and not quadratic), then the justification for blending CM with other protein sources is mainly price related. In contrast, if relationships between responses and $\mathrm{CM}$ inclusion are quadratic, then it may suggest issues related to nutrition and quality of CM as a protein source. Taking together the potential nutritional benefits associated with feeding $\mathrm{CM}$ and acknowledging that $\mathrm{CP}$ concentration of CM could vary between studies, our hypothesis was that production responses will be related linearly, but not quadratically, to the intake of $\mathrm{CP}$ from $\mathrm{CM}$ when cows are fed isonitrogenous diets. Therefore, the objective of the current meta-analysis was to conduct meta-analyses to quantitatively summarize the effects of the supply of CP from CM on production responses in isonitrogenous diets fed to lactating dairy cows while exploring the influence of factors on the relationships.

\section{MATERIALS AND METHODS}

\section{Data Set}

The Scopus online database was searched in August 2018 for studies in which canola or double-zero rapeseed coproducts were fed to lactating dairy cows. The following keywords were used: ruminant or cow, together with canola or rapeseed. The literature search was not restricted to North American journals and to publications in French and English languages. References in articles and review manuscripts were scrutinized in the search for new publications; thus, publications written in other languages could be included in the data set (e.g., Jahreis et al., 1995; written in German). A large collection of studies was assembled (385 treatment means from 94 publications), and the data set was downsized to studies that included 3 or more isonitrogenous dietary treatments.

The a priori inclusion criteria for the current metaanalysis were (1) within-study coefficient of variation for dietary CP concentration $\leq 0.05$ (DM basis), (2) number of replica, DMI, and production data measured on an individual-cow basis (cow as the experimental unit), (3) proportion of protein supplement $\geq 5 \%$ (wt/ wt, DM basis) in the ration, (4) at least 1 dietary con- 
trol treatment with $\mathrm{CM}<10 \%$ (wt/wt, DM basis) in the protein supplement, (5) at least 1 dietary treatment with $\mathrm{CM}>85 \%$ (wt/wt, DM basis) in the protein supplement, (6) at least 1 or more blended CM treatment with $10 \% \leq \mathrm{CM} \leq 85 \%$ in the protein supplement, and (7) information available on feed ingredients or ration composition to reconstitute the ration using NRC (2001). Despite an extensive literature search, few studies complied with all inclusion criteria. The final data set included 22 studies (74 treatment means) from 17 published manuscripts (Table 1).

The current study differs from previous meta-analyses (Huhtanen et al., 2011; Martineau et al., 2013, 2014) because it addresses a new research question requiring the evaluation of quadratic relationships on studies with 3 or more dietary treatments. As a result, only 10 dietary treatments were common to the current and the previous data set used by Martineau et al. (2013). In contrast with Martineau et al. (2013, 2014), metaregressions were conducted on treatment means (not delta values) and data were weighted by the inverse of sampling variance (see below).

\section{Calculations}

If not reported, MTPY was calculated as $0.95 \times$ milk $\mathrm{CP}$ yield. Milk component yield was calculated by multiplying milk yield (MY) and component percentage in Laarveld et al. (1981) and Trøan et al. (2018). In the latter studies and Papas et al. (1978), standard error (SE) of milk component yield was calculated by propagation of error (Taylor, 1997). In line with Steel et al. (1997), SE was computed by dividing SE of the difference between any 2 means by $\sqrt{2}$ (Macleod, 1991) and standard deviation (SD) by $\sqrt{n}$ (Jahreis et al., 1995).

Energy-corrected milk $(\mathrm{kg} / \mathrm{d})$ was calculated from MY (kg/d), MPY (kg/d), milk fat yield (MFY, kg/d), and milk lactose yield (MLY, $\mathrm{kg} / \mathrm{d}$ ) according to Sjaunja et al. (1991):

$$
\begin{aligned}
(0.01 \times \mathrm{MY})+ & (7.7 \times \mathrm{MPY})+(12.2 \times \mathrm{MFY}) \\
+ & (5.3 \times \mathrm{MLY})
\end{aligned}
$$

or

$$
(0.25 \times \mathrm{MY})+(7.7 \times \mathrm{MPY})+(12.2 \times \mathrm{MFY}) .
$$

If not reported, SE of ECM was calculated by propagation of error acknowledging that MY, MPY, MFY, and MLY were not independent variables and that propagated SE of ECM needed an adjustment. The adjustment factor was determined in studies reporting ECM,
MY, MPY, MFY, or MLY. First, the SD of ECM, MY, MPY, MFY, or MLY was calculated from reported SE of each variable. Second, propagated SD of ECM was calculated according to Neter et al. (1988) and using coefficients from Sjaunja et al. (1991):

$$
\begin{aligned}
{\left[\left(0.01 \times \mathrm{SD}_{\mathrm{MY}}\right)^{2}\right.} & +\left(7.7 \times \mathrm{SD}_{\mathrm{MPY}}\right)^{2}+\left(12.2 \times \mathrm{SD}_{\mathrm{MFY}}\right)^{2} \\
& \left.+\left(5.3 \times \mathrm{SD}_{\mathrm{MLY}}\right)^{2}\right]^{0.5}
\end{aligned}
$$

or

$$
\begin{aligned}
{\left[\left(0.25 \times \mathrm{SD}_{\mathrm{MY}}\right)^{2}+\left(7.7 \times \mathrm{SD}_{\mathrm{MPY}}\right)^{2}\right.} \\
\left.+\left(12.2 \times \mathrm{SD}_{\mathrm{MFY}}\right)^{2}\right]^{0.5}
\end{aligned}
$$

Third, the ratio between reported and propagated SD of ECM was $1.4 \pm 0.13(\mathrm{n}=39)$, indicating that MY, MPY, MFY, and MLY were not independent variables and supporting the adjustment to propagated SD of ECM. Therefore, in publications not reporting ECM, propagated SD of ECM was calculated and the SE of ECM was computed by dividing $(1.4 \times$ propagated SD of ECM) by $\sqrt{n}$ (Martineau et al., 2017).

Standard error estimates were trimmed and standardized to reduce biases created by very low SE and the use of different experimental designs and statistical procedures among studies. In the data set, studies were conducted using a Latin square (LS) or randomized block (RB) design and analyzed using a fixed-effect or mixed-effects statistical procedure. Therefore, 4 combinations were possible: LS-fixed, LS-mixed, and RBfixed (no RB-mixed; Table 1). Meta-regression models were weighted by the inverse of sampling variance; thus, very low SE could create an overweighting bias (Elliott, 2008). To reduce that bias, low SE estimates in each group of studies (e.g., LS-fixed) were trimmed to 0.4 or 0.5 of the mean of SE in each group; the cutoff level was chosen to trim approximately $10 \%$ of SE in each group of studies (Roman-Garcia et al., 2016). Overall, 58 out of $742 \mathrm{SE}$ estimates were trimmed in the data set.

The standardization of SE was done because SE estimates were assumed to be lowest in LS-fixed studies versus other groups of studies; SE are lowest for LS versus RB (Lean et al., 2009) and for fixed versus mixed (Littell et al., 1998). Trimmed SE estimates were standardized to unity in each group of studies and recentered on the overall mean of trimmed SE among all studies (Roman-Garcia et al., 2016; Robin R. White, Virginia Tech, Blacksburg, VA, personal communication). Thus, each dependent variable was weighted without bias for very low SE and for differences in experimental design and statistical procedure. 
EFFECT OF BLENDING CANOLA MEAL IN DAIRY RATIONS

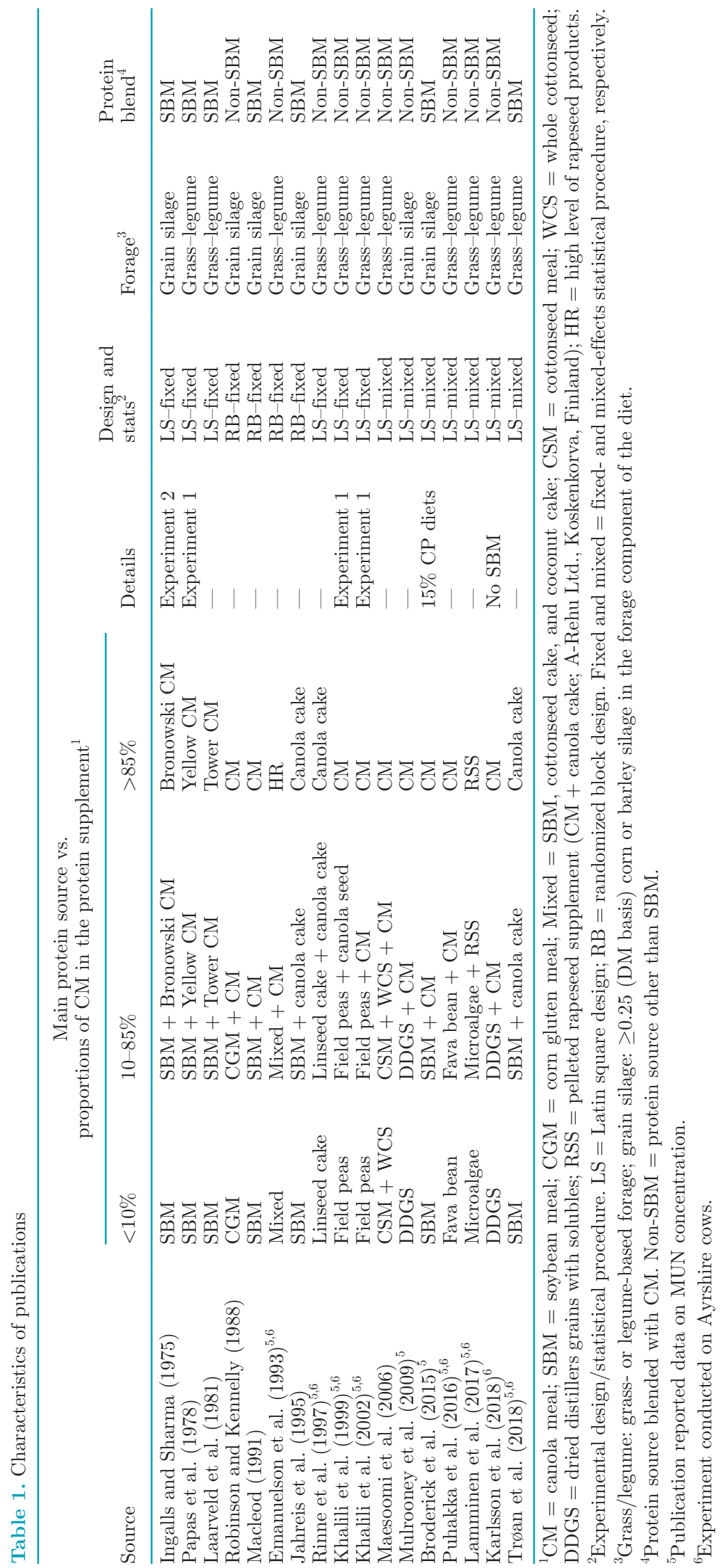


Table 2. Summary statistics for the cow-associated variables

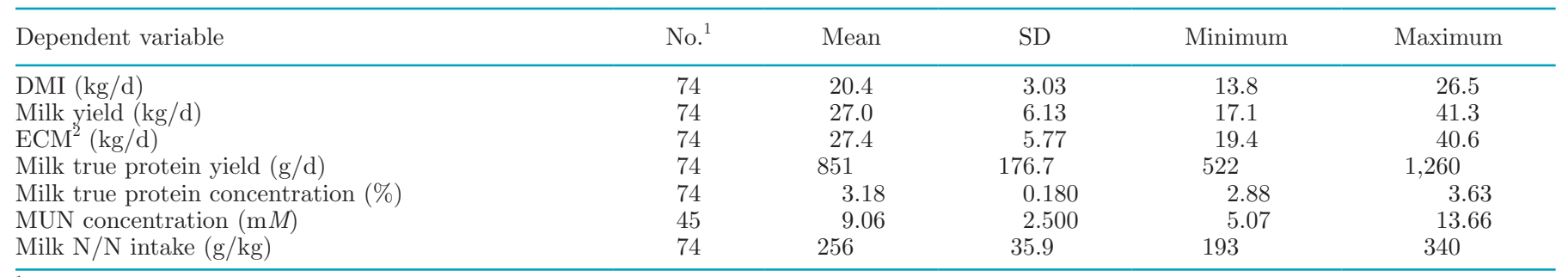

${ }^{1}$ Number of treatment means.

${ }^{2}$ Estimated according to Sjaunja et al. (1991) if not reported in the publication.

\section{Dependent and Independent Variables}

The summary statistics for cow-associated and moderator variables are reported in Tables 2 and 3, respectively. The dependent variables were DMI $(\mathrm{kg} / \mathrm{d})$, MY $(\mathrm{kg} / \mathrm{d})$, ECM $(\mathrm{kg} / \mathrm{d})$, MTPY $(\mathrm{g} / \mathrm{d})$, milk concentration of true protein (MTP\%), milk concentration of MUN $(\mathrm{m} M)$, and apparent $\mathrm{N}$ efficiency (milk $\mathrm{N} / \mathrm{N}$ intake, g/ $\mathrm{kg}$; Table 2). The predictor of interest was the dietary supply of CP from CM (in kg/d). Models were evaluated for the influence of 7 continuous moderators (Table 3). Moderators included MP supply (kg/d), $\mathrm{NE}_{\mathrm{L}}$ supply (Mcal/d), NE $\mathrm{L}_{\mathrm{L}}$ concentration (Mcal $/ \mathrm{kg}$ ), the proportion of concentrate (DM basis), and dietary concentrations (\% of DM) of CP, NDF, and ether extract (EE). In line with Martineau et al. (2011), feed ingredients as similar as possible to those reported in the publications were selected from the NRC (2001) feed library to reconstitute the ration. The chemical composition of each feed ingredient was used when reported; otherwise, values from the NRC (2001) feed library were used. The $\mathrm{CP}$ concentration of $\mathrm{CM}$ was not reported and set at 37.8\% (DM basis) for Laarveld et al. (1981), Macleod (1991), Robinson and Kennelly (1988), and Puhakka et al. (2016). The CP, NDF, and EE composition of the ration was calculated to be as close as possible to that reported in the publication. In Table 4, correlation coefficients between moderators were calculated using the cor.test function from the stats package in $R$.
Two categorical moderator variables were evaluated the current study (Table 1). Forage was dichotomized into grass-legume and grain silage (corn or barley silage $\geq 25 \%$ of DM in the forage component of the diet; Ingalls and Sharma, 1975; Robinson and Kennelly, 1988). Protein blend was dichotomized into SBM and non-SBM [e.g., corn gluten meal, dried distillers grains with solubles (DDGS)]. Most studies in which grasslegume forage was fed to dairy cows were supplemented with protein sources other than SBM (37 out of 48 treatment means); therefore, results are expected to be similar for grass-legume and non-SBM studies and careful interpretation needs to be done.

\section{Multilevel Mixed-Effect Meta-Regression Model}

The data had a hierarchical structure and data were fitted to a 3-level mixed-effect meta-regression model using the rma.mv function in the metafor package in $\mathrm{R}$ (REML method; Viechtbauer, 2010, 2016a,b). The variance component $\left(\sigma^{2}\right)$ was divided into 3 parts to indicate where most of the random variation was; that is, between (1) treatment means nested within a study itself nested within an experiment, (2) studies nested within an experiment, and (3) experiments. The sampling variance (vi) corresponding to each dependent variable was specified as the squared SE (Viechtbauer, 2010). The weight matrix was the inverse of the mar-

Table 3. Summary statistics for the moderator variables

\begin{tabular}{|c|c|c|c|c|c|c|c|}
\hline Variable & No. ${ }^{1}$ & Mean & $\mathrm{SD}$ & Minimum & $\begin{array}{c}\text { First } \\
\text { quartile }\end{array}$ & $\begin{array}{c}\text { Third } \\
\text { quartile }\end{array}$ & Maximum \\
\hline Protein supplement intake $(\mathrm{kg} / \mathrm{d})$ & 74 & 2.36 & 0.968 & 0.85 & 1.58 & 2.89 & 6.21 \\
\hline $\mathrm{CP}$ intake from canola meal $(\mathrm{kg} / \mathrm{d})$ & 74 & 0.46 & 0.413 & 0.00 & 0.00 & 0.68 & 1.55 \\
\hline MP supply $(\mathrm{kg} / \mathrm{d})$ & 74 & 1.93 & 0.343 & 1.21 & 1.73 & 2.21 & 2.64 \\
\hline $\mathrm{NE}_{\mathrm{L}}$ supply (Mcal/d) & 74 & 31.5 & 4.36 & 22.0 & 29.2 & 34.5 & 41.6 \\
\hline $\mathrm{NE}_{\mathrm{L}}$ concentration (Mcal/kg) & 74 & 1.54 & 0.057 & 1.44 & 1.50 & 1.60 & 1.66 \\
\hline Concentrate $(\%)$ & 74 & 45.0 & 7.58 & 33.6 & 39.1 & 50.0 & 60.5 \\
\hline $\mathrm{CP}(\%$ of $\mathrm{DM})$ & 74 & 15.9 & 1.07 & 13.3 & 15.1 & 16.8 & 18.0 \\
\hline $\mathrm{NDF}(\%$ of $\mathrm{DM})$ & 74 & 39.0 & 6.32 & 26.5 & 32.5 & 43.8 & 51.8 \\
\hline Ether extract (\% of DM) & 74 & 3.64 & 0.919 & 2.30 & 3.00 & 4.49 & 5.99 \\
\hline
\end{tabular}

\footnotetext{
${ }^{1}$ Number of treatment means.
} 
Table 4. Correlation coefficients between moderator variables ${ }^{1}$

\begin{tabular}{|c|c|c|c|c|c|c|c|}
\hline Variable & $\begin{array}{l}\text { MP } \\
\text { supply }\end{array}$ & $\begin{array}{c}\mathrm{NE}_{\mathrm{L}} \\
\text { supply }\end{array}$ & $\begin{array}{c}\mathrm{NE}_{\mathrm{L}} \\
\text { concentration }\end{array}$ & Concentrate & $\mathrm{CP}$ & $\mathrm{NDF}$ & $\begin{array}{l}\text { Ether } \\
\text { extract }\end{array}$ \\
\hline $\begin{array}{l}\mathrm{CP} \text { intake from } \mathrm{CM} \\
\mathrm{MP} \text { supply } \\
\mathrm{NE}_{\mathrm{L}} \text { supply } \\
\mathrm{NE}_{\mathrm{L}} \text { concentration } \\
\text { Concentrate } \\
\mathrm{CP} \\
\mathrm{NDF}\end{array}$ & $0.14^{0.25}$ & $\begin{array}{l}0.17^{0.14} \\
0.93^{<0.001}\end{array}$ & $\begin{array}{l}-0.17^{0.13} \\
-0.25^{0.03} \\
-0.18^{0.12}\end{array}$ & $\begin{array}{l}0.16^{0.18} \\
0.06^{0.59} \\
0.06^{0.60} \\
0.19^{0.11}\end{array}$ & $\begin{array}{c}-0.05^{0.66} \\
-0.26^{0.03} \\
-0.37^{0.001} \\
0.35^{0.002} \\
0.26^{0.02}\end{array}$ & $\begin{array}{c}-0.01^{0.93} \\
-0.72^{<0.001} \\
-0.77^{<0.001} \\
0.13^{0.26} \\
0.01^{0.92} \\
0.43^{<0.001}\end{array}$ & $\begin{array}{c}-0.07^{0.57} \\
-0.30^{0.008} \\
-0.22^{0.06} \\
0.61^{<0.001} \\
-0.04^{0.75} \\
0.18^{0.12} \\
0.35^{0.002}\end{array}$ \\
\hline
\end{tabular}

${ }^{1}$ All variables were calculated using NRC (2001). Refer to Table 3 for units of variables. CM = canola meal. Pearson's product-moment correlation; $\mathrm{df}=72 . P$-values are superscript.

ginal variance-covariance matrix, which is block-diagonal with vi $+\sigma_{\text {experiment }}^{2}+\sigma_{\text {study }}^{2}$ along the diagonal and $\sigma_{\text {experiment }}^{2}$ for off-diagonal elements that correspond to the same level of experiment (Viechtbauer, 2018b). In these models, the weight matrix ignored the underlying but unknown correlation of sampling errors within clusters. Therefore, unbiased estimates of fixed effects and valid estimates of SE were obtained using the robust function in the metafor package with the outermost nesting variable (experiment) as the clustering variable. Use of the robust function does not change the weight matrix but only affects the way the variance-covariance matrix of fixed effects and downstream SE and $P$-values are computed (Viechtbauer, 2017a,b,c).

The predictor of interest was forced in each model, and moderators other than the predictor of interest were retained in the model if they showed evidence of being a confounder in the data set; that is, their removal would result in a substantial change in the coefficient of the predictor of interest (Kleinbaum et al., 1998; Dohoo et al., 2003). The influence of each moderator on the linear relationship between the dependent variable and $\mathrm{CP}$ from $\mathrm{CM}$ was evaluated by including the "moderator $\times$ CP from CM" interaction in the model. If significant $(P \leq 0.05)$, the interaction term implied that the relationship between the dependent variable and $\mathrm{CP}$ from $\mathrm{CM}$ differed at every one of the infinite values of the moderator. For categorical moderators, the interaction was evaluated using the rma.mv function and allowing the amount of residual heterogeneity to be different in each level of the categorical moderator [Viechtbauer (2017d) adapted by Martineau et al. (2019)]. The interested readers can refer to Martineau et al. (2017) for a full description of the statistical model notation.

The vif.rma function of metafor was used in all models to obtain the variance inflation factors (VIF) to diagnose potential multicollinearity among the independent variables. The VIF value assesses how much the variance of a regression coefficient increases in the presence of multicollinearity: 1 implies no correlation,
5 to 10 suggests high correlation that may be problematic, and $>10$ indicates that the model will result in poor estimation of coefficients, which should be handled accordingly (Akinwande et al., 2015). Terms correlated by calculation (squared and interaction terms) were allowed to have VIF $>10$; however, terms that were not correlated by calculation were removed if VIF was $>5$.

The generalized and weighted least squares extension of Cochran's Q-test when moderators are included in the model ( $\boldsymbol{Q E}$-test) was computed for each model. The $Q E$-test examines whether there is any additional variability in the residuals than one would expect based on the sampling variability alone (Viechtbauer, 2018a). The higher the $Q E$-test value, the greater is the unexplained variance left in the residuals after moderators have been added to the model. Potential outlying observations and studies were detected using the rstandard, rstudent, and cook.distance functions in the metafor package. The meta-design and relationships were graphed using the ggplot function of the ggplot2 package for R (Wickham, 2009) to reveal potential outliers and evaluate relationships. Other functions in the metafor package were used to reveal (1) profile likelihood plots of the variance components (profile. rma.mv), (2) various aspects and assumptions of the data (qqnorm), and (3) occurrence of a publication bias (funnel).

In this article we refer to probabilities $\leq 0.05$ as significant and probabilities of $0.05<P \leq 0.10$ as a tendency. This research project received approval from the Animal Care and Use Committee from the Sherbrooke Research Centre (Sherbrooke, QC, Canada) according to Canadian Council on Animal Care (2009) guidelines.

\section{RESULTS AND DISCUSSION}

\section{Features of the Data Set and the Meta-Design}

Figure 1 depicts the isonitrogenicity of dietary treatments in each study as the within-study coefficient of variation of dietary $\mathrm{CP}$ concentration averaged $0.01 \pm$ 


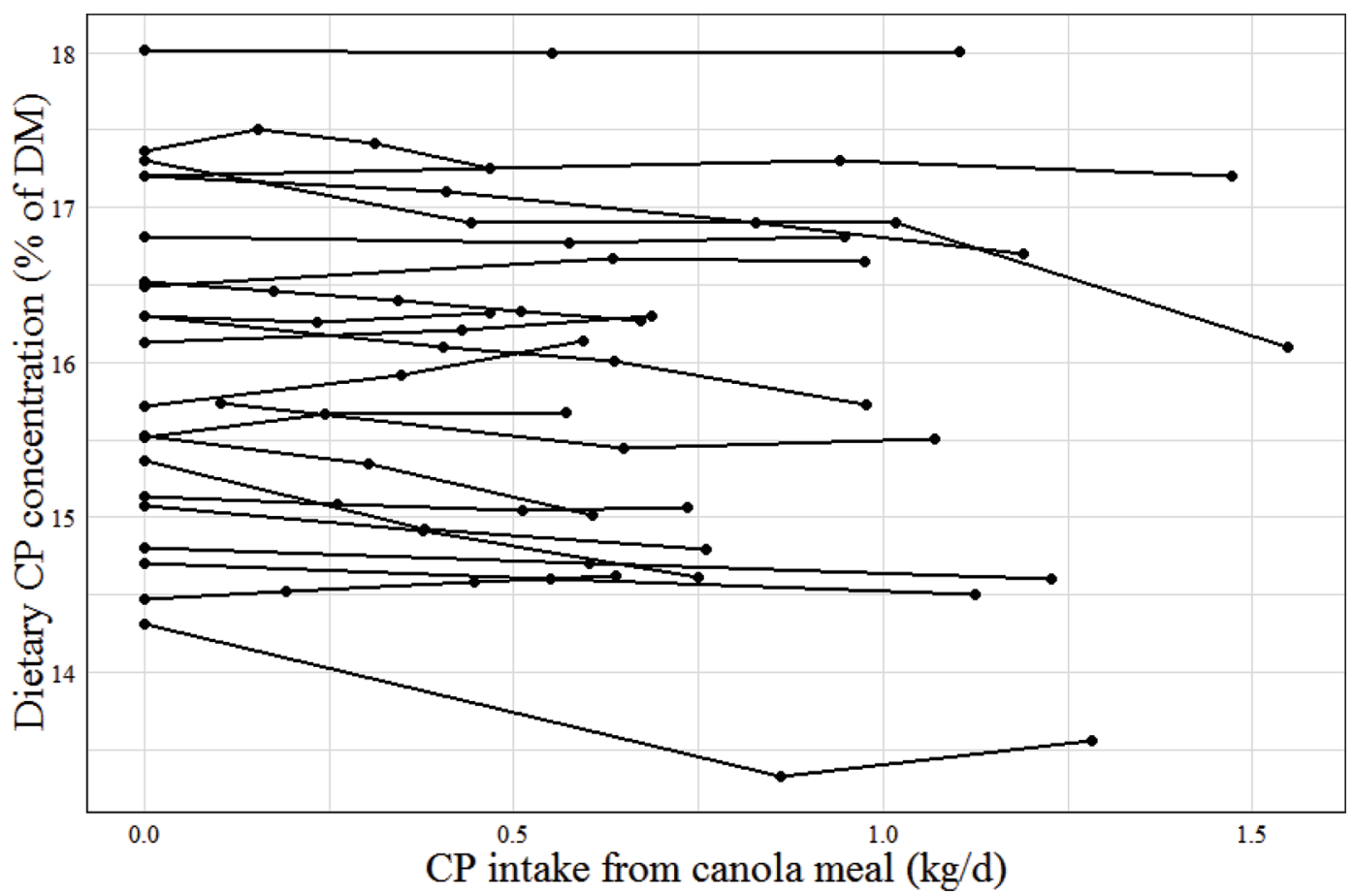

Figure 1. Meta-design showing dietary CP concentration versus the intake of CP from canola meal. Each study is depicted by a line connecting 2 or more dots.

0.009 (range $=0.000-0.037$ ). The maximal daily intake of CP from CM ranged from 0.47 to $1.55 \mathrm{~kg} / \mathrm{d}$ among studies. The proportion of protein supplement in the ration averaged $11.5 \pm 0.04 \%$ (range $=5.9-21.0 \%)$, and the proportion of $\mathrm{CM}$ in the protein supplement averaged $0.4 \pm 1.75 \%$ (range $=0.0-8.2 \% ; \mathrm{n}=22$ ) in control treatments and $98.8 \pm 3.25 \%$ (range $=85.6-100.0 \% ; \mathrm{n}$ $=22$ ) in $\mathrm{CM}$ treatments. In CM treatments, the proportion of CM in the protein supplement was $100.0 \%$ in all studies except Emanuelson et al. $(1993 ; 96.2 \%)$ and Maesoomi et al. (2006; 85.6\%).

\section{Relationships Between Production Responses and the Intake of CP from CM}

Quadratic Relationships. Responses in MTP\% were related $(P=0.006)$ quadratically to $\mathrm{CP}$ from $\mathrm{CM}$ but not the other dependent variables $(P \geq 0.37$; Table $5)$. In the current study, the maximum MTP\% (3.19\%) was reached at a daily intake of $0.79 \mathrm{~kg}$ of $\mathrm{CP}$ from $\mathrm{CM}$. In their review of nutritional factors influencing milk components, DePeters and Cant (1992) indicated that a depression in MTP\% might be due to a dilution effect because MY increased to a greater extent than MTPY in many studies. Dietary fat can also reduce MTP\% because it has a greater effect on the synthesis of nonnitrogenous components of milk than on milk protein synthesis itself. Except for DDGS, the
EE concentration is higher in $\mathrm{CM}$ versus other protein sources (SBM, corn gluten meal, linseed meal, cottonseed meal; NRC, 2001), and one can calculate that CM will supply $143 \mathrm{~g}$ of $\mathrm{EE} / \mathrm{kg}$ of $\mathrm{CP}$ versus an average of $41 \mathrm{~g}$ of $\mathrm{EE} / \mathrm{kg}$ of $\mathrm{CP}$ for the low-EE protein sources listed above (NRC, 2001). DePeters and Cant (1992) also discussed in depth the concept of AA limitations on milk protein synthesis. These AA limitations are minimized when providing high-quality protein (e.g., postruminal casein infusion) and maximizing the efficiency of MCP synthesis. A recent meta-analysis by Martineau et al. (2017) showed concomitant increases in MY, MTPY, and MTP\% to incremental MP supplied by postruminal infusion of casein, indicating that casein provided limiting AA for milk protein synthesis. Although CM is recognized as a high-quality protein source, the heat-moisture treatment of CM can provide favorable conditions for the Maillard reaction to occur, inducing a loss of AA, particularly Lys, and reducing the bioavailability of all AA (Newkirk et al., 2003). In the current data set, heat-treated CM was used in the studies of Rinne et al. (1997), Puhakka et al. (2016), Karlsson et al. (2018), and Trøan et al. (2018) with no clear negative effect on responses in MTP\%. The typical plateau- or bell-shaped pattern was observed in the studies of Rinne et al. (1997) and Karlsson et al. (2018) but was not significant. This is in line with responses in $\mathrm{MTP} \%$ to heat treatment of $\mathrm{CM}$, which 
have been inconsistent (Tuori, 1992) and not conclusive (Ahvenhjärvi et al., 1999; Wright et al., 2005; Paula et al., 2018). Huhtanen et al. (2011) reported that the true $\mathrm{CP}$ digestibility was reduced in heat-treated $\mathrm{CM}$ versus $\mathrm{CM}$ but with no effect on production responses as dietary $\mathrm{CP}$ concentration increased. Heat treatment of CM had no effect on the omasal flow of $\mathrm{N}$ fractions (Ahvenhjärvi et al., 1999; Paula et al., 2018), but the omasal flow and plasma concentration of essential AA were not reported in these studies. Therefore, more research is warranted on the effects of feeding heat-treated $\mathrm{CM}$ in high-producing dairy cow diets, particularly on the duodenal flow of nutrients and the bioavailability of AA.

Overall, within the limits of the data available, the results of the current meta-analysis indicate that there is no benefit of blending CM with another protein source in dairy rations in terms of production responses. In fact, blending protein sources might be useful to alleviate potential limitations in terms of AA profile because the inclusion of $\mathrm{CM}$ in dairy rations can increase plasma concentrations of all essential AA (Martineau et al., 2014).

Linear Relationships. Linear relationships were positive $(P \leq 0.02)$ for responses in DMI, MY, ECM, MTPY, MTP $\%$, and apparent $\mathrm{N}$ efficiency but negative $(P=0.002)$ for responses in MUN (Table 5; Figure $2)$. The relationships were in line with previous findings from Martineau et al. (2013, 2014). Several models were controlled for MP supply and NDF, indicating that the slope of $\mathrm{CP}$ from CM changed substantially if these moderators were removed from the model. For responses in MTPY, the slope of CP from CM would be 43.2 (not 79.4) $\mathrm{g}$ of MTPY $/ \mathrm{kg}$ of CP from CM and the $Q E$-test would more than triple (reaching 3,730) with no other independent variable in the model (Akaike's information corrected criterion $=789$; data not shown). These results indicate that MP supply was underestimated in $\mathrm{CM}$ diets versus diets supplemented with other protein sources using NRC (2001), in line with Martineau et al. (2013). If MP supply was to increase proportionally to the inclusion of CM in the diet (e.g., $100 \mathrm{~g}$ of MP supply $/ \mathrm{kg}$ of $\mathrm{CP}$ from $\mathrm{CM}$ ), the slope of $\mathrm{CP}$ from $\mathrm{CM}$ would decrease accordingly and MP supply would no longer be a confounder variable (i.e., similar coefficient of $\mathrm{CP}$ from $\mathrm{CM}$ with and without MP supply in the model).

The most important factors affecting production responses and the efficiency of $\mathrm{N}$ utilization in dairy cows are the efficiency of MCP synthesis and the duodenal profile of digestible essential AA, which should be closely related to the composition of the cow's milk (except for His). The AA profile of rumen bacteria varies with dietary characteristics (Hvelplund, 1986; Sok et al., 2017), and the contribution of microbial NAN to omasal NAN flow can exceed 70\% (Olmos Colmenero and Broderick, 2006; Brito et al., 2007). Therefore, production responses and the efficiency of $\mathrm{N}$ utilization are prone to imbalances in some essential AA from the forage and concentrate components of the diet because the MCP and the RUP fraction of the diet determine the flow and profile of digestible AA. One main advantage of $\mathrm{CM}$ is its balanced $\mathrm{AA}$ profile compared with other protein sources (NRC, 2001), which makes CM suitable RDP and RUP sources for several feeding conditions. Maxin et al. (2013) reported that feeding a CM diet resulted in a better quality of MP supply compared with SBM (low Met), corn high-protein dried distillers grains (low Lys), and wheat DDGS (low His). Compared with these protein sources, CM presented no deficiency or imbalance in a single essential AA.

The factors significantly influencing the relationship between $\mathrm{CP}$ from $\mathrm{CM}$ and the responses in $\mathrm{MTP} \%$ and MUN are reported in Table 6. Responses in MTP\% to $\mathrm{CP}$ from $\mathrm{CM}$ were influenced positively by $\mathrm{NE}_{\mathrm{L}}$ concentration and dietary fat; indeed, both factors are correlated and influenced the relationship in the same direction (Table 4). From data reported in Table 6, one can calculate that the slopes of CP from CM would be, respectively, 0.005 and $0.064 \%$ at first and third quartiles of dietary $\mathrm{NE}_{\mathrm{L}}$ concentration and 0.016 and $0.092 \%$ at first and third quartiles of dietary EE concentration. These effects are mainly on a between-studies basis, indicating that responses in MTP\% (or protein synthesis) to $\mathrm{CP}$ from $\mathrm{CM}$ were better in studies with high $\mathrm{NE}_{\mathrm{L}}$ concentration, high EE concentration, or both. Note that all studies with dietary EE concentration $>3.60 \%$ of DM were conducted on Ayrshire cows fed grass-legume-based diets, except the study of Mulrooney et al. (2009), and in studies in which CM replaced non-SBM protein sources (data not shown). In line with the study of Martineau et al. (2013), responses in MTP\% were related $(P \leq 0.01)$ positively to $\mathrm{CP}$ from $\mathrm{CM}$ in studies based on grass-legume forages and in non-SBM studies (Table 6); however, these effects cannot be dissociated because of the meta-design.

The results indicate that $\mathrm{CM}$ alleviated some essential AA deficiencies related to feeding grass-legumebased diets (e.g., His), non-SBM diets (e.g., Lys), or both in lactating dairy cows. Histidine has been identified as the first limiting AA for milk protein synthesis in cows fed grass silage-based diets (Vanhatalo et al., 1999; Korhonen et al., 2000; Kim et al., 2001). In fact, the limitation was likely more due to (1) CP of silage being extensively degraded in the rumen and (2) lowHis MCP contributing largely to MP supply. The same limitation of His was observed in high-producing dairy cows fed MP-deficient corn silage- and alfalfa haylage- 


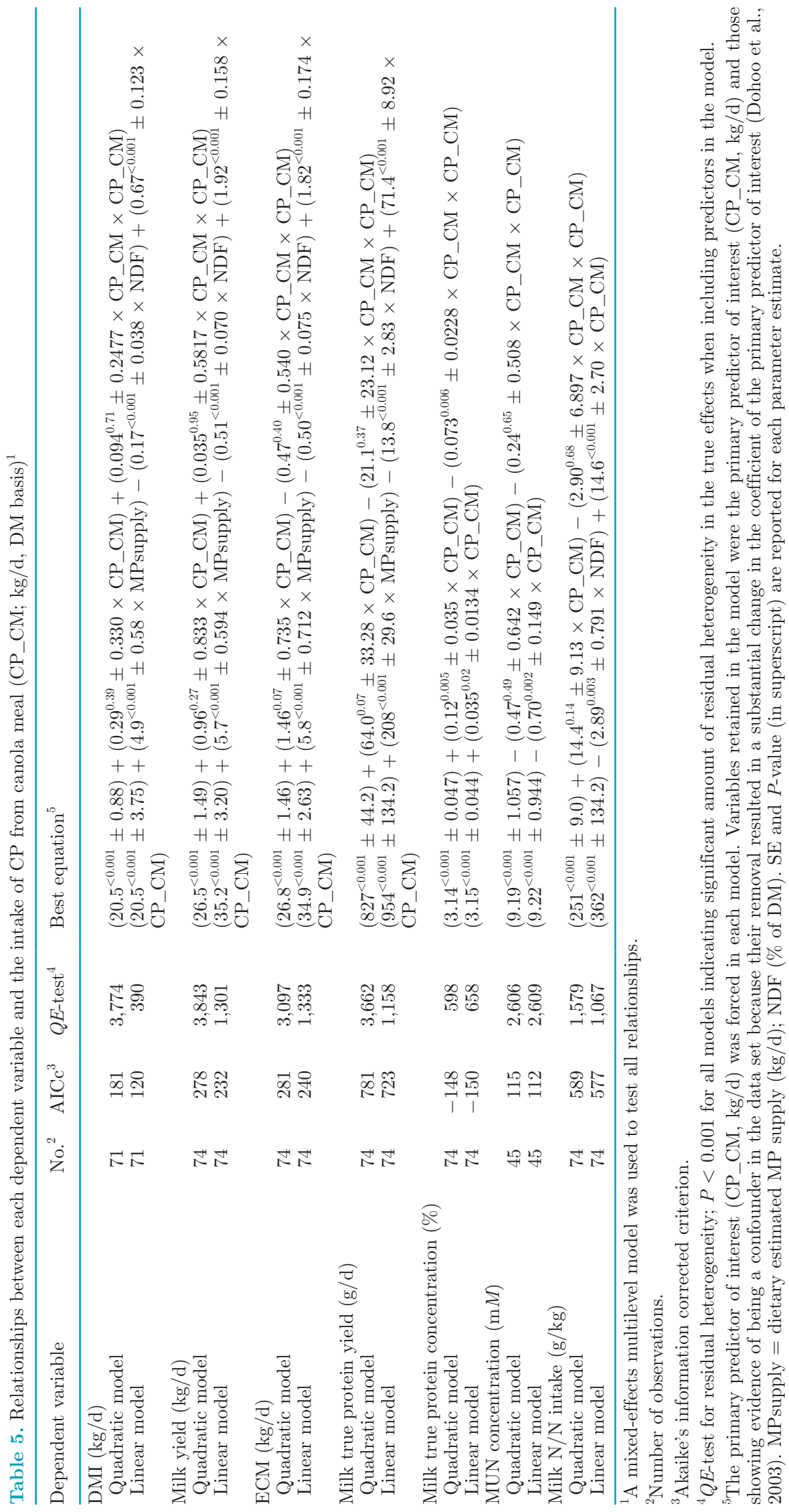



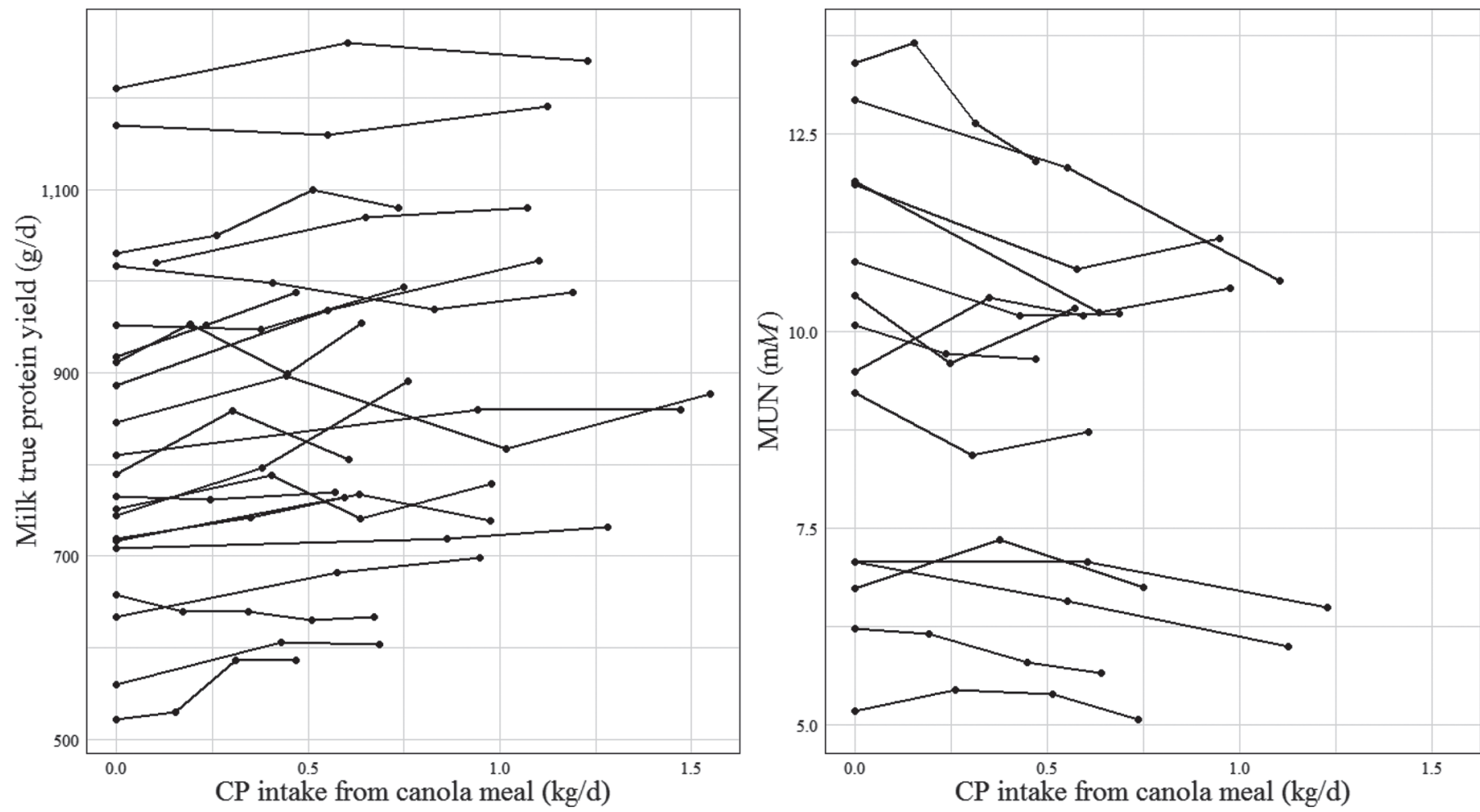

Figure 2. Meta-design showing milk true protein yield and MUN concentration versus the intake of CP from canola meal. Each study is depicted by a line connecting 2 or more dots.

based diets and relying heavily on low-His MCP (Lee et al., 2012). The positive effect of feeding CM on milk protein synthesis in non-SBM studies could be associated with a positive effect of $\mathrm{CM}$ on Lys and other essential AA. In the study of Mulrooney et al. (2009), plasma concentrations of Ile and Lys increased linearly as more CM replaced DDGS, as did the extraction ratio of His, Phe, and Val by the mammary gland. The effect on the plasma AA profile is not surprising because cornbased products are poor in Lys (Schingoethe, 1996) and the Lys content of $\mathrm{CM}$ is more than twice that of DDGS (5.62 vs. $2.24 \%$ of CP, respectively; NRC, 2001). Indeed, blending DDGS with CM is viewed as a way of solving one of the main concerns surrounding the use of DDGS in dairy rations by increasing the supply of Lys.

Responses in MUN to CP from CM were influenced negatively by the dietary $\mathrm{CP}$ concentration (Table 6). From responses in MUN, one can calculate that the slopes of CP from CM would be, respectively, -0.438 and $-1.332 \%$ at first and third quartiles of $\mathrm{CP}$ concentration for responses in MUN, indicating that less AA were oxidized when feeding $\mathrm{CM}$ in diets with high $\mathrm{CP}$ concentration. This effect could be associated with CM replacing a protein source with a higher RDP concentration in high-CP studies. For example, responses in MUN decreased significantly as heat moisture-treated rapeseed cake replaced cold-pressed linseed cake in the study of Rinne et al. (1997; CP $=17.4 \%$ of DM among dietary treatments).

Overall, results indicate that feeding CM has a positive effect on production responses and the whole-body $\mathrm{N}$ utilization efficiency by the animal because more dietary protein is utilized to synthesize milk protein, this being reflected by higher apparent $\mathrm{N}$ efficiency and lower MUN concentrations. Within the limits of the data available, the current meta-analysis does not indicate that blending $\mathrm{CM}$ with another protein source would be more beneficial for production responses versus supplementing CM alone up to $1.55 \mathrm{~kg} / \mathrm{d}$. Indeed, more research is required with higher levels of dietary $\mathrm{CM}$ and with heat-treated CM fed to the high-producing dairy cow. Finally, the current study replicated the findings of Martineau et al. $(2013,2014)$ for a complete substitution of SBM and other protein sources by CM but using a different set of studies and new methodological and statistical approaches.

\section{CONCLUSIONS}

A meta-analysis was conducted to evaluate the linear and quadratic relationships between production responses and the supply of $\mathrm{CP}$ from $\mathrm{CM}$ in isonitrog- 


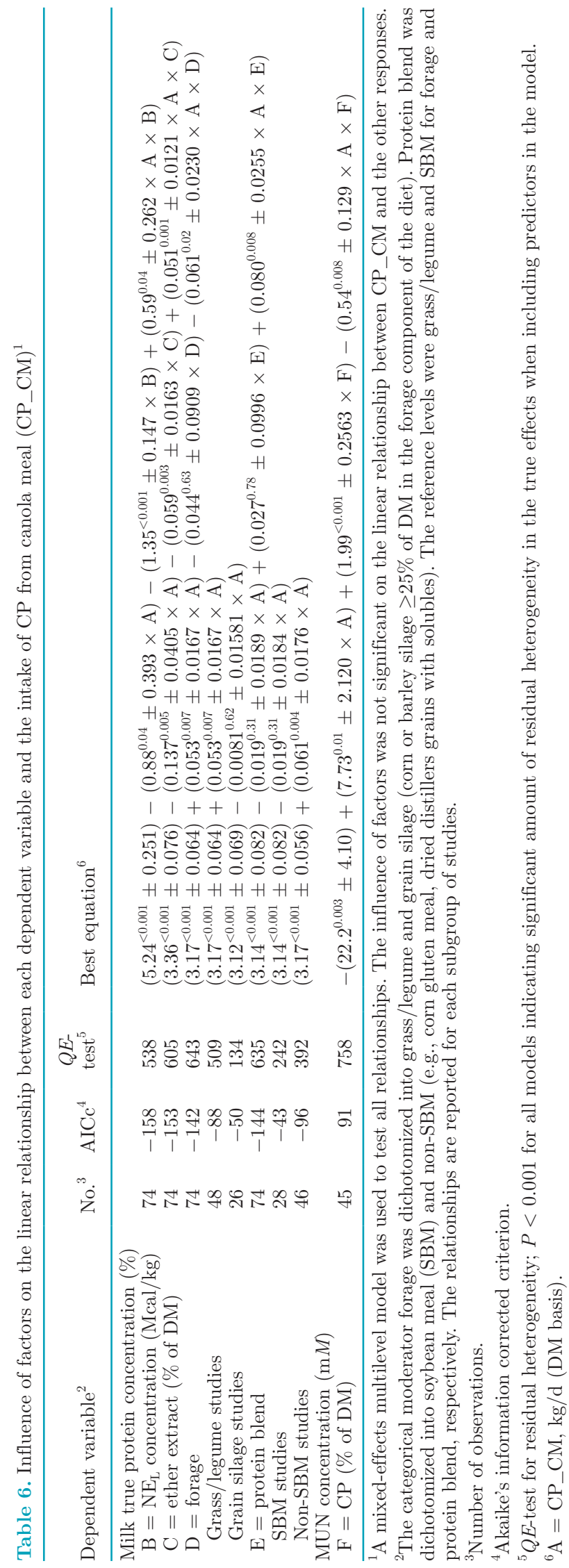

enous diets fed to dairy cows. Isonitrogenous studies with 3 or more dietary treatments conducted on lactating dairy cows and covering 4 decades of research were used in the current meta-analysis. Only responses in milk true protein concentration were related quadratically to the supply of CP from CM (the marginal increase decreasing as the supply of $\mathrm{CP}$ from $\mathrm{CM}$ increased). The same quadratic relationship was observed in grass-legume studies and in non-SBM studies. The quadratic relationship did not reach significance for the other dependent variables, and responses in DMI and production were related linearly and positively to the supply of CP from CM. Therefore, the current study does not support the idea that blending CM with other protein sources will outperform the positive production responses obtained by supplementing $\mathrm{CM}$ alone up to $1.55 \mathrm{~kg} / \mathrm{d}$.

\section{ACKNOWLEDGMENTS}

The authors gratefully thank the Canola Council of Canada (Winnipeg, MB, Canada) and Agriculture and Agri-Food Canada (Sherbrooke, QC, Canada) for their financial support. The authors are grateful to Robin R. White (Virginia Tech, Blacksburg) for sharing with us the $\mathrm{R}$ script for the trimming and standardization procedure of standard error estimates.

\section{REFERENCES}

Abbadi, A., and G. Leckband. 2011. Rapeseed breeding for oil content, quality, and sustainability. Eur. J. Lipid Sci. Technol. 113:11981206.

Ahvenhjärvi, S., A. Vanhatalo, P. Huhtanen, and T. Varvikko. 1999. Effects of supplementation of a grass silage and barley diet with urea, rapeseed meal and heat-moisture-treated rapeseed cake on omasal digesta flow and milk production in lactating dairy cows. Acta Agric. Scand. A Anim. Sci. 49:179-189.

Akinwande, M. O., H. G. Dikko, and A. Samson. 2015. Variance inflation factor: As a condition for the inclusion of suppressor variable(s) in regression analysis. Open J. Stat. 5:754-767.

Bach, A., S. Calsamiglia, and M. D. Stern. 2005. Nitrogen metabolism in the rumen. J. Dairy Sci. 88(E-Suppl.):E9-E21.

Brito, A. F., G. A. Broderick, and S. M. Reynal. 2007. Effects of different protein supplements on omasal nutrient flow and microbial protein synthesis in lactating dairy cows. J. Dairy Sci. 90:18281841

Broderick, G. A., A. P. Faciola, and L. E. Armentano. 2015. Replacing dietary soybean meal with canola meal improves production and efficiency of lactating dairy cows. J. Dairy Sci. 98:5672-5687.

Canadian Council on Animal Care. 2009. Guide to the Care and Use of Experimental Animals. 2nd ed. Vol. 1. E. D. Rolfert, B. M. Cross, and A. A. McWilliam, ed. CCAC, Ottawa, ON, Canada.

DePeters, E. J., and J. P. Cant. 1992. Nutritional factors influencing the nitrogen composition of bovine milk: A review. J. Dairy Sci. $75: 2043-2070$.

Dohoo, I., W. Martin, and H. Stryhn. 2003. Model-building strategies. Pages 317-334 in Veterinary Epidemiologic Research. AVC Inc., Prince Edward Island, Canada.

Elliott, M. R. 2008. Model averaging methods for weight trimming. J. Off. Stat. 24:517-540. 
Emanuelson, M., K. Å. Ahlin, and H. Wiktorsson. 1993. Long-term feeding of rapeseed meal and full-fat rapeseed of double low cultivars to dairy cows. Livest. Prod. Sci. 33:199-214.

Hill, R. 1991. Rapeseed meal in the diets of ruminants. Nutr. Abstr. Rev. (Series B) 61:139-155.

Huhtanen, P., M. Hetta, and C. Swensson. 2011. Evaluation of canola meal as a protein supplement for dairy cows: A review and a metaanalysis. Can. J. Anim. Sci. 91:529-543.

Hvelplund, T. 1986. The influence of diet on nitrogen and amino acid content of mixed rumen bacteria. Acta Agric. Scand. 35:325-331.

Illg, D. J., J. L. Sommerfeldt, and D. J. Schingoethe. 1987. Lactational and systemic responses to the supplementation of protected methionine in soybean meal diets. J. Dairy Sci. 70:620-629.

Ingalls, J. R., and H. R. Sharma. 1975. Feeding of Bronowski, Span and commercial rapeseed meals with or without addition of molasses or flavor in the rations of lactating cows. Can. J. Anim. Sci. 55:721-729

Jahreis, G., G. H. Richter, H. Hartung, G. Flachowsky, and F. Lübbe. 1995. Einsatz von Rapskuchen in der Milchviehfütterung und Einfluß auf die Milchqualität [Use of rapeseed cake in dairy cow feeding and influence on milk quality]. Das Wirtschaftseigenen Futter. 41:99-114.

Karlsson, J., R. Spörndly, M. Lindberg, and K. Holtenius. 2018. Replacing human-edible feed ingredients with by-products increases net food production efficiency in dairy cows. J. Dairy Sci. 101:7146-7155.

Khalili, H., E. Kuusela, E. Saarisalo, and M. Suvitie. 1999. Use of rapeseed and pea grain protein supplements for organic milk production. Agric. Food Sci. Finland 8:239-252.

Khalili, H., E. Kuusela, M. Suvitie, and H. Huhtanen. 2002. Effect of protein and energy supplements on milk production in organic farming. Anim. Feed Sci. Technol. 98:103-119.

Kim, C. H., J. J. Choung, and D. G. Chamberlain. 2001. Responses of milk production to the intravenous infusion of amino acids in dairy cows given diets of grass silage and cereal-based supplements. J. Anim. Physiol. Anim. Nutr. (Berl.) 85:293-300.

Kleinbaum, D. G., L. L. Kupper, K. E. Muller, and A. Nizam. 1998. Confounding and interaction in regression. Pages 186-211 in Applied Regression Analysis and Other Multivariable Methods. G. Kleinbaum, L. L. Kupper, A. Nizam, and K. E. Miller, ed. Duxbury Press, Pacific Grove, CA.

Korhonen, M., A. Vanhatalo, T. Varvikko, and P. Huhtanen. 2000. Responses to graded postruminal doses of histidine in dairy cows fed grass silage diets. J. Dairy Sci. 83:2596-2608.

Laarveld, B., R. P. Brockman, and D. A. Christensen. 1981. The effects of Tower and Midas rapeseed meals on milk production and concentrations of goitrogens and iodide in milk. Can. J. Anim. Sci. 61:131-139.

Lamminen, M., A. Halmemies-Beauchet-Filleau, T. Kokkonen, I. Simpura, S. Jaakkola, and A. Vanhatalo. 2017. Comparison of microalgae and rapeseed meal as supplementary protein in the grass silage based nutrition of dairy cows. Anim. Feed Sci. Technol. 234:295-311

Lean, I. J., A. R. Rabiee, T. F. Duffield, and I. R. Dohoo. 2009. Invited review: Use of meta-analysis in animal health and reproduction: Methods and applications. J. Dairy Sci. 92:3545-3565.

Lee, C., A. N. Hristov, T. W. Cassidy, K. S. Heyler, H. Lapierre, G. A Varga, M. J. de Veth, R. A. Patton, and C. Parys. 2012. Rumenprotected lysine, methionine, and histidine increase milk protein yield in dairy cows fed a metabolizable protein-deficient diet. J. Dairy Sci. 95:6042-6056.

Littell, R. C., P. R. Henry, and C. B. Ammerman. 1998. Statistical analysis of repeated measures data using SAS procedures. J. Anim. Sci. 76:1216-1231.

Macleod, G. K. 1991. Canola meal as a protein supplement in corn based dairy rations. Pages 255-264 in Research on Canola Seed, Oil, and Meal. Ninth Project Report. Canola Council of Canada, Winnipeg, MB, Canada.

Maesoomi, S. M., G. R. Ghorbani, M. Alikhani, and A. Nikkhah. 2006. Short communication: Canola meal as a substitute for cottonseed meal in diet of midlactation Holsteins. J. Dairy Sci. 89:1673-1677.
Martineau, R., D. R. Ouellet, and H. Lapierre. 2013. Feeding canola meal to dairy cows: A meta-analysis on lactational responses. J. Dairy Sci. 96:1701-1714.

Martineau, R., D. R. Ouellet, and H. Lapierre. 2014. The effect of feeding canola meal on concentrations of plasma amino acids. J. Dairy Sci. 97:1603-1610.

Martineau, R., D. R. Ouellet, and H. Lapierre. 2017. Relationships between postruminal casein infusion and milk production, and concentrations of plasma amino acids and blood urea in dairy cows: A multilevel mixed-effects meta-analysis. J. Dairy Sci. 100:80538071.

Martineau, R., D. R. Ouellet, R. A. Patton, R. R. White, and H. Lapierre. 2019. Plasma essential amino acid concentrations in response to casein infusion or ration change in dairy cows: A multilevel, mixed-effects meta-analysis. J. Dairy Sci. 102:1312-1329.

Martineau, R., D. Sauvant, D. R. Ouellet, C. Côrtes, J. Vernet, I. Ortigues-Marty, and H. Lapierre. 2011. Relation of net portal flux of nitrogen compounds with dietary characteristics in ruminants: A meta-analysis approach. J. Dairy Sci. 94:2986-3001.

Maxin, G., D. R. Ouellet, and H. Lapierre. 2013. Effect of substitution of soybean meal by canola meal or distillers grains in dairy rations on amino acid and glucose availability. J. Dairy Sci. 96:7806-7817.

Mulrooney, C. N., D. J. Schingoethe, K. F. Kalscheur, and A. R. Hippen. 2009. Canola meal replacing distillers grains with solubles for lactating dairy cows. J. Dairy Sci. 92:5669-5676.

Neter, J., W. Wasserman, and G. A. Whitmore. 1988. Random variables. Pages 146-184 in Applied Statistics. 3rd ed. Allyn and Bacon, Newton, MA.

Newkirk, R. W., H. L. Classen, T. A. Scott, and M. J. Edney. 2003. The availability and content of amino acids in toasted and nontoasted canola meals. Can. J. Anim. Sci. 83:131-139.

NRC. 2001. Nutrient Requirements of Dairy Cattle. 7th rev. ed. Natl. Acad. Sci., Washington, DC.

Olmos Colmenero, J. J., and G. A. Broderick. 2006. Effect of dietary crude protein concentration on ruminal nitrogen metabolism in lactating dairy cows. J. Dairy Sci. 89:1694-1703.

Papas, A., J. R. Ingalls, and P. Cansfield. 1978. Effects of Tower and 1821 rapeseed meals and Tower gums on milk yield, milk composition and blood parameters of lactating dairy cows. Can. J. Anim. Sci. 58:671-679.

Paula, E. M., G. A. Broderick, M. A. C. Danes, N. E. Lobos, G. I. Zanton, and A. P. Faciola. 2018. Effects of replacing soybean meal with canola meal or treated canola meal on ruminal digestion, omasal nutrient flow, and performance in lactating dairy cows. J. Dairy Sci. 101:328-339.

Piepenbrink, M. S., and D. J. Schingoethe. 1998. Ruminal degradation, amino acid composition and estimated intestinal digestibilities of four protein supplements. J. Dairy Sci. 81:454-461.

Puhakka, L., S. Jaakkola, I. Simpura, T. Kokkonen, and A. Vanhatalo. 2016. Effects of replacing rapeseed meal with fava bean at 2 concentrate crude protein levels on feed intake, nutrient digestion, and milk production in cows fed grass silage-based diets. J. Dairy Sci. 99:7993-8006.

Rinne, M.. S. Jaakkola, M. Järvi, and P. Huhtanen. 1997. Effects of gradual replacement of rapeseed cake with linseed cake in a grass silage-based diet for dairy cows. Agric. Food Sci. Finland 6:161172.

Robinson, P. H. 2010. Impacts of manipulating ration metabolizable lysine and methionine levels on the performance of lactating dairy cows: A systematic review of the literature. Livest. Sci. 127:115126

Robinson, P. H., and J. J. Kennelly. 1988. Influence of intake of rumen undegradable protein on milk production of late lactation Holstein cows. J. Dairy Sci. 71:2135-2142.

Robinson, P. H., and N. Swanepoel. 2018. Impacts of increasing levels of canola meal in diets of high producing Holstein cows on their productive performance. Anim. Feed Sci. Technol. 237:175-185.

Roman-Garcia, Y., R. R. White, and J. L. Firkins. 2016. Meta-analysis of postruminal microbial nitrogen flows in dairy cattle. I. Derivation of equations. J. Dairy Sci. 99:7918-7931. 
Sauvant, D., J. M. Perez, and G. Tran. 2004. Tables of Composition and Nutritional Value of Feed Materials: Pigs, Poultry, Cattle, Sheep, Goats, Rabbits, Horses, Fish. Wageningen Academic Publishers, Wageningen, the Netherlands.

Schingoethe, D. J. 1996. Balancing the amino acid needs of the dairy cow. Anim. Feed Sci. Technol. 60:153-160.

Schwab, C. G., C. K. Bozak, and N. L. Whitehouse. 1992. Amino acid limitation and flow to the duodenum at four stages of lactation. 1. Sequence of lysine and methionine limitation. J. Dairy Sci. 75:3486-3502.

Shahidi, F. 1990. Rapeseed and canola: Global production and distribution. Pages 3-13 in Canola and Rapeseed: Production, Chemistry, Nutrition, and Processing Technology. F. Shahidi, ed. Van Nostrand Reinhold, New York, NY.

Sjaunja, L. O., L. Bævre, I. Junkkarinen, J. Pedersen, and J. Setälä. 1991. A Nordic proposal for an energy corrected milk (ECM) formula. Pages 156-157 in 27th Session of the International Committee of Recording and Productivity of Milk Animal, Paris, France. EAAP Publication No. 50. Wageningen Academic Publishers, Wageningen, the Netherlands.

Sok, M., D. R. Ouellet, J. L. Firkins, D. Pellerin, and H. Lapierre. 2017. Amino acid composition of rumen bacteria and protozoa in cattle. J. Dairy Sci. 100:5241-5249.

Steel, R. G. D., J. H. Torrie, and D. A. Dickey. 1997. Principles and Procedures of Statistics: A Biometrical Approach. 3rd ed. McGraw-Hill, New York, NY.

Swanepoel, N., P. H. Robinson, and L. J. Erasmus. 2014. Determining the optimal ration of canola meal and high protein dried distillers grain protein in diets of high producing Holstein dairy cows. Anim. Feed Sci. Technol. 189:41-53.

Taylor, J. 1997. Introduction to Error Analysis, the Study of Uncertainties in Physical Measurements. 2nd ed. University Science Books, South Orange, NJ.

Trøan, G., J.-M. Pihlava, A. Brandt-Kjelsen, B. Salbu, and E. Prestløkken. 2018. Heat-treated rapeseed expeller press cake with extremely low glucosinolate content reduce transfer of iodine to cow milk. Anim. Feed Sci. Technol. 239:66-73.

Tuori, M. 1992. Rapeseed meal as a supplementary protein for dairy cows on grass silage-based diets, with the emphasis on the Nordic AAT-PBV feed protein evaluation system. Agric. Sci. Finland $1: 367-439$.
Vanhatalo, A., P. Huhtanen, V. Toivonen, and T. Varvikko. 1999. Response of dairy cows fed grass silage diets to abomasal infusions of histidine alone or in combinations with methionine and lysine. J. Dairy Sci. 82:2674-2685.

Viechtbauer, W. 2010. Conducting meta-analyses in R with the metafor package. J. Stat. Softw. 36:1-48.

Viechtbauer, W. 2016a. Meta-analysis via multivariate/multilevel linear (mixed-effects) models. Accessed Jan. 30, 2018. https://rdrr .io/cran/metafor/man/rma.mv.html.

Viechtbauer, W. 2016b. The metafor package. A meta-analysis package for R. Accessed Jan. 30, 2018. http://www.metafor-project .org/doku.php/analyses:konstantopoulos2011.

Viechtbauer, W. 2017a. [R-meta] multilevel meta-analysis using metafor. Accessed Jan. 30, 2018. https://stat.ethz.ch/pipermail/r-sig -meta-analysis/2017-August/000174.html.

Viechtbauer, W. 2017b. [R-meta] multilevel meta-analysis using metafor. Accessed Jan. 30, 2018. https://stat.ethz.ch/pipermail/r-sig -meta-analysis/2017-September/000188.html.

Viechtbauer, W. 2017c. [R-meta] multilevel meta-analysis using metafor. Compute (cluster) robust test and confidence intervals for 'rma' objects. Accessed Jan. 30, 2018. https://www.rdocumentation .org/packages/metafor/versions/1.9-9/topics/robust.

Viechtbauer, W. 2017d. The metafor package. A meta-analysis package for R. Comparing estimates of independent meta-analyses or subgroups. Accessed Jan. 30, 2018. http://www.metafor-project .org/doku.php/tips:comp_two_independent_estimates.

Viechtbauer, W. 2018a. Package 'metafor'. Meta-analysis package for R. Version 2.0-0. Accessed Jun. 1, 2018. https://cran.r-project .org/web/packages/metafor/metafor.pdf.

Viechtbauer, W. 2018b. [R-meta] Weighing factors in rma.mv corresponding to those used in lmer. Accessed Mar. 29, 2018. https: //stat.ethz.ch/pipermail/r-sig-meta-analysis/2018-March/000731 .html.

Wickham, H. 2009. ggplot2: Elegant Graphics for Data Analysis. Springer-Verlag, New York, NY.

Wright, C. F., M. A. von Keyserlingk, M. L. Swift, L. J. Fisher, J. A. Shelford, and N. E. Dinn. 2005. Heat- and lignosulfonate-treated canola meal as a source of ruminal undegradable protein for lactating dairy cows. J. Dairy Sci. 88:238-243. 